\title{
TWO THEORIES IN REGARD TO THE IMPLIED POWERS OF THE CONSTITUTION.
}

In his lecture upon "Man as a Member of a Confederation," James Wilson, Lecturer on Law to the College of Philadelphia, which was soon to be united with the University of Pennsylvania, said, "Great minds frequently unite, without intercommunication, upon the same great object." The reference was to Henry the Fourth of France and Elizabeth of England. To Elizabeth had come the vision of a united Europe; to Henry she had communicated the vision, and his mind, quick and receptive as hers was fertile, had seized upon the thought, and to Sully he had intrusted the working out of the practical details of a scheme both came to believe might be accomplished. A dream of great minds, destined not to be brought to any visible, concrete, embodiment in that world for which they dreamed and labored. But Wilson believed that in this new world to which he had come, this America he had learned to love, their "sublime system" had been "effectually realized." In this federal republic he saw the dream of Elizabeth and Henry brought into complete realization. For he believed that in the union of states under a federal constitution there had come into being a system of government such as had never before been tried in the known history of the world.

Mr. Wilson was a signer of the Declaration of Independence, an ardent, untiring supporter of the struggling confederacy during the war, and one of the most eminent and active members of the convention which framed the Constitution of 1787 . Prominent in the debates, a member of the committee on detail, it is probable that as fully as any person in the United States he understood the document he had helped to form. It should not therefore be considered as presumptuous to claim for him a priority in certain ideas which have since been widely disseminated by another great

${ }^{1}$ Wilson's Works, vol. I, p. 335.

214 
mind. Such minds, as we have seen, "frequently unite without intercommunication." It is no disparagement to the one that the other has reached a like level where he has been able to gain a similar breadth of view. To those who may not be able to reach this level, it is no unpleasing thought that upon these uplands of the intellect the one does not dwell alone in the loneliness of his high thoight, but that it there has the inspiring companionship of an equal mind.

John Marshall has been honored as the moulder of our thought upon the Constitution; and the honor has been well bestowed. But because he reached the high levels of constitutional interpretation it is not a necessary consequence that he should stand alone upon those levels. We have, perhaps, a little, in these latter days, fallen into a habit of thinking that because " the expounder." lived and enunciated his principles in years succeeding those which saw the forming of the Constitution, the fathers, lacking the light he has thrown upon it, did not wholly comprehend the work of their own minds. Or, understanding it, would have given to it a narrower interpretation than, under the leadership of Marshall, it has since received. To any one who has made a study of the life and work of James Wilson, it must become apparent that he, at least, understood and interpreted the Constitution with as broad a mind, as clear a knowledge, a vision as far-seeing, as ever has been brought to its consideration. It may be truly said that he not only thoroughly understood it after it was formulated and had taken its place among the governments of the world, but there is not lacking proof that he had analysed and mentally digested the principles upon which it would be necessary to base its interpretations, before the idea of a federal constitution had fully taken shape.

The case of $M c C$ ulloch v. Maryland ${ }^{2}$ has often been cited as the cornerstone of the constitutional fabric in regard to the implied powers of the constitution, and as "probably Marshall's greatest opinion." "If we regard at once the greatness of the questions at issue in the particular case,

\footnotetext{
${ }_{4}^{3}$ Wheaton, 316.
} 
the influence of the opinion, and the large method and clear and skilful manner in which it is worked out; there is nothing so fine as the opinion in McCullocli v. Maryland. The questions were, first, whether the United States could constitutionally incorporate a bank; and, second, if it could, whether a state might tax the operation of the bank."3 This case was decided by Judge Marshall in 1819 . In 1785 , nearly a quarter of a century earlier, but when Marshall was thirty years of age, and at a time when he was a member of the Virginia legislature, thus being in touch with the thought of the time on all important questions, James Wilson published his "Considerations on the Bank of North America." The Bank of North America had been granted a charter of incorporation by an act of Congress, in 1781 , and the Legislature of Pennsylvania had passed a supplementary Act, in $\mathbf{I 7 8 2}$. The publication of these considerations was occasioned by a bill introduced into the Legislature of Pennsylvania, to repeal the act incorporating the bank. The question Wilson had to consider was, as he states it , " $\mathrm{Had}$ the United States in congress assembled a legal and constitutional power to institute and organize the Bank of North America, by a charter of incorporation? The question in McCulloch v. Maryland, as stated by Marshall was, "Has congress the power to incorporate a bank?" Marshall had to interpret the Constitution of 1787 , Wilson the Articles of Confederation. But they had to discuss the same principles and to apply them to a similar state of facts.

The first objection to the power thus claimed was thatin one case by the Articles of Confederation, in the other by the Constitution-certain express powers had been granted, or delegated, by the sovereign states to the national government, and that the power to incorporate a bank was not one of them. Wilson conceded that it was true that-

\footnotetext{
"By the second article of the confederation, "each state retains its sovereignty, freedom and independence, and every power, jurisdiction, and right, which is not, by the confederation, expressly delegated to

sDillon. Marshall: Life, Character and Judicial Services. vol. I, Address of Professor Thayer, p. 234.
} 
the United States in congress assembled.' If, then, any of the states possessed, previous to the confederation, a power, jurisdiction, or right, to institute and organize, by a charter of incorporation, a bank for North America; in other words commensurate to the United States, such power, jurisdiction, and right, unless expressly delegated to Congress, cannot be legally or constitutionally exercised by that body."

"But, we presume, it will not be contended, that any or each of the states could exercise any power or act of sovereignty extending over all the other states, or any of them; or, in other words, incorporate a bank, commensurate to the United States."

"The consequence is, that this is not an act of sovereignty, or a power, jurisdiction, or right, which, by the second article of the confederation, must be expressly delegated to congress, in order to be possessed by that body."

\section{Marshall argued as follows:}

"This government is acknowledged by all to be one of enumerated powers. The principle that it can exercise only the powers granted to it would seem to be too apparent to have required to be enforced by all those arguments which its enlightened friends, while it was depending before the people, found it necessary to urge . . . If any one proposition could command the universal assent of mankind, we might expect that it would be this-that the government of the Union, though limited in its powers, is supreme within its sphere of action. This would seem to. resilt necessarily from its nature It is the government of all; its powers are delegated by all; it represents all; and acts for all. Though any one state may be willing to control its operations, no state is willing to allow others to control them . . The government of the United States, then, though limited in its powers, is supreme; and its laws when made in pursuance of the Constitution, form the supreme law of the land, anything in the constitution or laws of any state to the contrary notwithstanding." "

"Among the enumerated powers, we do not find that of establishing a bank or creating a corporation. But there is no phrase in the instrument which, like the Articles of Confederation, excludes incidental or implied powers; and which requires that everything granted shall be expressly and minutely described."

This last paragraph shows the limitation of Marshall's thought on the subject. In finding a basis for his argument he went as far back as the reeds of the specific occasion demanded, and he went no further. The ground on which he took his stand was sufficient for the foundation of the edifice he was to erect, and it seemed sufficiently firm. But he did not reach quite to the basic rock which it would be found necessary to reach in order to sustain the greater

- Wilson's Works, vol. 3, p. 405.

- McCulloch v. Maryland, 4 Wheaton, $405,406$. 
fabric which was to come, and the ground which he covered was later found not sufficient for the expanding greatness of the structure. ${ }^{6}$

Having thus decided that the United States in congress assembled had only delegated powers, or that it was a government of enumerated powers, both Marshall and Wilson took the next step necessary to demonstrate that, nevertheless, the power to incorporate a bank was within the scope of the Constitution.

\section{Marshall argued that-}

A government, entrusted with such ample powers, on the due execution of which the happiness and prosperity of the nation so vitally depends, must also be entrusted with ample means for their execution.

And upon this necessity in the national government for the means to carry out the powers either expressly or impliedly granted to it he based his argument for the right of congress to incorporate a bank.

"On what foundation does this argument rest? On this alone: The power of creating a corporation is one appertaining to sovereignty, and is not expressly conferred on Congress. This is true. But all legislative powers appertain to sovereignty. The original power of giving the law on any subject whatever is a sovereign power; and if the government of the Union is restrained from creating a corporation, as a means for performing its functions, on the single reason that the creation of a corporation is an act of sovereignty: if the sufficiency of this reason be acknowledged there would be some difficulty in sustaining the authority of Congress to pass other laws for the accomplishment of the same objects." "

"The government which has a right to do an act, and has imposed on it the duty of performing that act, must, according to the dictates

\footnotetext{
- For example it has been considered that the peaceful acquisition of territory, a national banking system, or the acts making anything other than gold and silver coin a legal tender, are not properly included within the scope of Marshall's argument.

" New states must be formed and established: their extent and boundaries must be regulated and ascertained. How can this be done, unless by the United States in congress assembled? ... I have asked, How can new states, which are bodies politick, be formed, unless by the United States in congress assembled? Fact, as well as argument, justifles my sentiment on this subject The conduct of congress has been similar on similar occasions. The same principles have directed the exercise of the same powers.... It will be
} 
of reason, be allowed to select the means; and those who contend that it may not select any appropriate means, that one particular means of effecting the object is excepted, take upon themrelves the burden of establishing that exception."

"It must have been the intention of those who gave these powers, to insure, as far as human prudence could insure, their beneficial execution. This could not be done by confining the choice of means to such narrow limits as not to-leave it in the power of Congress to adopt any which might be appropriate, and which were conducive to the end." . . . The clause " is placed among the powers of Congress, not among the limitations on those powers. . . Its terms purport to enlarge, not to diminish, the powers vested in the government. It purports to be an additional power, not a restriction on those already granted. . . The result of the most careful and attentive consideration bestowed upon this clause is, that if it does not enlarge, it cannot be construed to restrain, the powers of Congress, or to impair the right of the legislature to exercise its best judgment in the selection of measures to carry into execution the constitutional powers of the government. If no other motive for its insertion can doubts respecting the right to legislate on that vast mass of incidental powers which must be involved in the Constitution, if that instrument be suggested, a sufficient one is found in the desire to remove all be not a splendid dauble."

"We admit, as all must admit, that the powers of the government are limited, and that its limits are not to be transcended. But we think the sound construction of the Constitution must allow to the national legislature that discretion, with respect to the means by which the powers it confers are to be carried into execution, which will enable that body to perform the high duties assigned to it in the manner most beneficial to the people. Let the end be legitimate, let it be within the scope of the Constitution, and all means which are appropriate, which are plainly adapted to that end, which are not prohibited, but consist with the letter and spirit of the constitution, are constitutional." 10

The last words are the familiar household words of our constitutional law. Though said to have been "originated by Mr. Hamilton and paraphrased by Chief Justice Marshall "11 the paraphrase owes its vitality to Marshall's use of it. Hamilton's or Marshall's, it was a good working

difficult, I believe, to urge against the power of congress to grant a charter to the Bank of Noth America any argument which may not, with equal strength and fitness, be urged against the power of that body to form, execute, and promulgate a charter of compact for the new states" Wilson's Works vol. 3, pp. 408, 410, 4Ir. Phila. 1804.

"McCulloch v Maryland, 4 Wheaton, 409, 410.

"Congress shall have power"... "to make all laws which shall be necessary and proper to carry into execution" the powers of the government.

${ }^{10}$ McCulloch v. Maryland, 4 Wheaton, pp. 420, 42I.

21 Patterson. United States and the States under the Constitution, p. I6 $2 d$ ed. Philadelphia 1904 . 
theory. Whether Marshall himself would have agreed to the extension of that theory over subjects it has since been made to cover, can only be a matier of speculation to be answered in accordance with the private views of the investigator.

Jefferson, although Marshall's phrasing of the thought was still in the future, found the real weakness of the idea, in that it throws us back upon the need of determining what ends are legitimate. He says-

"It would reduce the whole instrument to a single phrase-that of instituting a congress with power to do whatever would be for the good of the United States . . . It was intended to lace them up strictly within the enumerated powers, and those without which, as means, these powers could not be carried into effect. It is known that the very power now proposed as a means, was rejected as an end by the corivention which formed the constitution. A proposition was made to them, to authorize Congress to open canals, and an amendatory one to empower them to incorporate. But the whole was rejected; and one of the reasons of objection urged in debate was, that they then would have power to erect a bank, which would render great cities, where there were prejudices and jealousies on that subject, adverse to the reception of the constitution."

Jefferson would, in principle, have objected to Mr. Wilson's line of argument, although he could not have made the specific objection, made here, for Wilson's argument, though leading to quite as broad an interpretation of the Constitution, rested upon fundamentally different grounds. Hamilton and his disciple Marshall, however, were more solicitous for the strength of the central government than they were for securing to the states their individual rights. Not so Wilson. He was a strong believer in the state governments. His experience during the existence of the Confederacy had taught him to desire, to see the necessity of, a strong national government. He invented a phrase, "Federal Liberty," to express his feelings in regard to the national government, but that phrase had as an essential ingredient the idea of the states joining in the common government for the freedom of all. In the course of the debates in the Federal Convention he often spoke of the

${ }^{12}$ Elliott's Debates, vol. 4, Appendix, p. 6 ro. 
necessity for preserving the state governments; he observed that-

"By a national government, he did not mean one that would swallow up the state governments, as seemed to be wished by some gentlemen. He was tenacious of the idea of preserving the latter. He thought, contrary to the opinion of Colonel Hamilton, that they might not only subsist, but on friendly terms with the former. They were absolutely necessary for certain purposes, which the former could not reach."

"The states should resign to the national government that part, and that part only, of their political liberty, which placed in that government, will produce more good to the whole than if it had remained in the several states. While they resign this part of their political liberty, they retain the free and generous exercise of all their faculties as states, so far as it is compatible with the welfare of the general and super-intending confederacy."

Marshall did not consider the power of establishing a corporation,-in the specific case, a bank,- to be an end intended by the Constitution. If it had been, he argues, it would have found a place among the enumerated powers of the government.

"But being considered merely as a means, to be employed only for the purpose of carrying into execution the given powers, there could be no motive for particularly mentioning it." is

The necessity for a bank was also advanced as an argument by both Marshall and Wilson, the latter citing authority after authority to show that all governments and financiers had found some such means necessary in carrying on the great operations of their governments. He showed the deep distress into which the United States had fallen during the war,-the hopes of the enemy that the finances would fail.

"This was the source of our fears, as well as the hopes of our enemies. By this thread our fate was suspended. We watched it with anxiety; we saw it stretched and weakened every hour; the deathful instrument was ready to fall upon our heads; on our heads it must have fallen, had not publick credit, in a moment when it was about to break asunder, been entwined and supported by the credit of the bank." "Marshall said, "All those who have been concerned in the

${ }^{13}$ Elliott's Debates, vol. 5, p. 212.

"Wilson's Works, vol. 3 , p. 288 . Philadelphia 1804.

${ }^{25}$ McCulloch v. Maryland, 4 Wheaton, p. 422.

${ }^{18}$ Wilson's Works, vol. 3 , p. 425. 
administration of our finances have concurred in representing its importance and necessity; and so strongly have they been felt, that statesmen of the first class, whose previous opinions against it had been confirmed by every circumstance which can fix the human judgment have yielded those opinions to the exigencies of the nation."

\section{Taking up again Wilson's argument in favor of the bank,} we find him arguing as follows :18

"Though the United States in congress assembled derive from the particular states no power, jurisdiction, or right, which is not expressly delegated by the confederation, it does not thence follow, that the United States in congress have no other powers, jurisdiction, or rights, than those delegated by the particular states."

"The United States have general rights, general powers, and general obligations, not derived from any particular states, taken separately; but resulting from the union of the whole; and, therefore, it is provided, in the fifth article of the confederation, that for the more convenient management of the general interests of the United States, 'Delegates shall be annually appointed to meet in congress." "

"To many purposes, the United States are to be considered as one undivided, independent nation; and as possessed of all the rights, and powers, and properties, by the law of nations incident to such."

"Whenever an object occurs, to the direction of which no particular state is competent, the management of it must, of necessity, belong to the United States in congress assembled. There are many objects of this extended nature. The purchase, the sale, the defence, and the government of lands and countries, not within any state, are all included under this description. An institution for circulating paper, and establishing its credit over the whole United States, is naturally ranged in the same class."

"The Act of Independence was made before the Articles of Confederation. This act declares, that 'these United Colonies' (not enumerating them separately) 'are free and independent states, they have full power to do all acts and things which independent states may, of right, do." "

"The confederation was not intended to weaken or abridge the powers and rights to which the United States were previously entitled. It was not intended to transfer any of those powers or rights to the particular states, or any of them. If, therefore, the power now in question was vested in the United States before the confederation; it continues vested in them still. The confederation clothed the United States with many, though, perhaps, not with sufficient powers; but of none did it disrobe them."

"It is no new position, that rights may be vested in a political body, which did not previously reside in any or in all the members of that body. They may be derived solely from the union of those members. (2 Burl. 42) 'The case,' says the celebrated Burlamaqui, ' is here very near the same as in that of several voices collected together, which, by their union, produce a harmony, that was not to be found separately in each." "

${ }^{17}$ McCulloch v. Maryland, 4 Wheaton, pp. 422, 423.

"McCulloch v. Maryland, 4 Wheaton, p. 421 . 
"A number of unconnected inhabitants are settled on each side of a navigable river. It belongs to none of them; it belongs to them all, for they have nothing in common; let them unite; the river is the property of the united body." 10

The argument here made is plain, logical, and, it is submitted, conclusive. Had it been given to the world in an opinion delivered before a court of law, necessarily to be consulted before other questions of a similar nature could be passed upon, it seems that it might have laid to rest many vexed questions which have been, and to some extent still are, unsettled. Marshall's opinion in McCulloch v. Maryland has been called a restatement from the supreme bench of this argument.20

The ground taken, the inferences drawn, do, indeed, seem similar; there is even a familar sound about some of the phrasing, about the grouping of ideas in some of the sentences; but, as has been before intimated, Wilson's argument is wider in its scope, and includes an important element not to be found in Marshall's much more labored and elaborate argument. Mr. Wilson argued that the states retained all the powers not expressly delegated. That if any power was possessed by a state before the union, and was not expressly delegated, it did not pass to the congress of the United States. But, he argued, if the power in question was not possessed by any state before the union, it was not a power which must be delegated in order to be possessed by that body. It was a power not derived from any particular state, or from all the particular states taken separately, but resulting from a union of the whole. When, therefore an object occurred, not within the power of any particular state, the management of it must, of necessity, belong to the United States in Congress assembled. As no state, at any time, had possessed any power over the other states, either singly or taken together, it must follow that all the powers which were needed by congress in regard to national concerns, or concerns which included more than one state, or involved con-

"Wilson's Works, vol. 3 pp. 406, 408. Philadelphia I804.

${ }^{20}$ Andrews, Wilson's Works, vol. I, p. 556, Note. Chicago, I8g6. 
trol of matters outside the bounds of any one state, must be vested in the United States by the constitution. It is very probable that Wilson's familiarity with the civil law gave him this clearer view of the position of the states to the nation than was taken by those unfamiliar with that branch of the law. He speaks of his position as no new one, and does not seem to feel that he is taking a position in any way radical or unusual. Marshall had, so far as is known, no knowledge of the civil law, and could, therefore, derive no help from it. Although from certain inward indications, as we have noticed, it seems likely that he had read the "Considerations," it is not probable that his mind had done more than assimilate unconsciously certain phrasings and, possibly, a part of the argument. It seems certain that he did not remember the line of argument upon which Wilson based his decision. For, in his decision, we see his mind laboring with the task he has in hand; we do not so much listen to the argument as we see him shaping it out for himself. We may see him emerge triumphantly from the difficulties which surround him, but we feel that we have watched a struggle. But in Wilson's argument we find no trace of a struggle. There is a sense of certainty from the moment of the opening paragraph. The matter has been met and conquered before we are admitted upon the scene; the labor has been accomplished and we see only the smooth, polished, perfect result.

The likeness between the arguments. of Marshall and Wilson are seen in the working out of the idea; the unlikeness is found in the grounds upon which the reasoning is based. As we have seen, both were profoundly convinced that there was an absolute necessity to uphold the power to incorporate; that this was a power given by the Constitution on the one hand, by the Articles of Confederation on the other. Both sought for a constitutional basis for the power they believed so necessary for the carrying on of the government. Marshall maintained that it would have been impossible that "everything granted shall be expressly and minutely described," but that there was nothing which, "like 
the Articles of Confederation, excludes incidental or implied powers." He seemed to feel, however, that this doctrine of the implied powers might make too wide a breach in the Constitution, for he adds, a little later, "it can never be pretended that these vast powers" (those enumerated) "draw after them others of inferior importance, merely because they are inferior. Such an idea can never be advanced." He feels that he must not admit the power of congress to incorporate under the Constitution, on the ground that this power is an inferior one, as that might lead to results in the future he might have to regret; that it might admit as constitutional powers which might not be, as he felt this power was, a necessity to the government. And then he finds his solution and the rest of the argument is comparatively easy. The power of incorporation was not of sufficient dignity to be included among the enumerated powers, but it could not be considered as implied for that reason; he admits that; but, he says, the congress must have the necessary means of carrying out the powers granted it. The power to incorporate is a necessary means for carrying out the ends intended to be gained through the enumerated powers. Therefore, as a means, and as a means only, the power is a constitutional power. It was a wise, a conservative, an ingenious, method, of upholding the power, and, as he hoped, of escaping the undesirable consequences. Unfortunately for his hopes, the interpreters of his decision have, probably without being conscious that they were doing so, and using his arguments to sustain their own; uncovered the sophism that lay concealed in its logic. They have thus carried the decision to the same length it would have gone, had he frankly discarded his doctrine regarding the "means," and rested his argument for the constitutionality of the power solely on the grounds that it was one of the unexpressed or implied powers. By inventing his subsidiary doctrine he seems simply to have added one more step to the reasoning, and those who have come after him, while apparently adopting his theory, have found it as easy to claim all desired powers as means, as they would have found it to 
claim them as ends inferior and not therefore not expressed. They seem to have found as great a freedom as they would have had under the doctrine he rejected. He has not in fact saved the Constitution from the wider construction he seems to have been desirous to avoid.

Marshall's argument would not have admitted the power to incorporate a bank to be constitutional under the articles of confederation. There is nothing in the Constitution, he thinks, which excludes the implied powers, "like the Articles of Confederation." Wilson had to deal with the Articles of Confederation, and he was still able to uphold the power; and he did it by enunciating a doctrine which at once delivered him from the embarrassments felt by Marshall; which would, indeed, open the door for as wide a construction as would the doctrine of implied powers in its broadest acceptation, but which he yet felt to be in no way an infringement upon the reserved powers of the states. He gave, as it were, to the confederated bodies, a soul, whose powers were in no way derived from the separate states; whose existence was the result solely of their union; whose life was dependent on their life; and therefore he felt no fear on its part of action from it inimical to the life of those states upon which its own life depended.

He states his doctrine simply, clearly, without circumlocution, or any show of feeling that he was admitting too much, or opening the door to unforseen evils. He felt no difficulty, and there is no sense of any in reading his argument.

Wilson's theory may not be considered sound. It may be, as Marshall felt the plain doctrine of implied powers would be, a very wide contruction of the Constitution. But did it not lead to the same conclusion? Did it admit more than Marshall's doctrine of the-means-to-the-end theory has been made to admit, by the conscious or unconscious ignoring of the limitations he tried to set, by treating his decision as if it admitted powers as wide as those fully and frankly claimed by Wilson?

It may be that one reason for the similarity of result, through a really profound difference of reasoning, in the argument of Marshall and of Wilson, is that they both seem 
to have had the same idea as to the ultimate seat of the sovereignty of our government. Marshall notes that the opponents of the bank claimed that the powers of the general government were delegated by the states, "who alone are truly sovereign;" and must be exercised in subordination to the states," who alone possess supreme dominion." $\left({ }^{21}\right) \mathrm{He}$ replies that "it would be difficult to sustain this proposi-. tion."..."The government of the union, then,...is, emphatically, and truly, a government of the people. . In form and in substance it emanates from them. Its powers are granted by them, and are to be exercised directly on them, and for their benefit." 22 He does not, however, ever appear to have expressed the thought as strongly as Wilson, who reiterated his opinions on this point time after time, and upon every occasion when he felt that there could by any possibility be any misunderstanding of the matter. He was perhaps more definite in his remarks before the Pennsylvania convention in 1787 , than anywhere else. He asks on one occasion-

"Upon what principle is it contended that the sovereign power resides in the state governments? . . My position is that the sovereignty resides in the people; they have not parted with it; they have only dispensed such portions of power as were conceived necessary for the public welfare. This Constitution stands upon this broad principle . . . When the principle is once settled that the people are the source of authority, the consequence is, that they may take from the subordinate rovernments powers with which they have hitherto intrusted them, and place those powers in the general government, if it is thought that it will be productive of more good. They can distribute one portion of power to the more contracted circle, called state govermments; they can also furnish another proportion to the government of the United States . . . How comes it, sir, that that these state governments dictate to their superiors-to the majesty of the people? . . . . I have no idea that a safe system of power in the government, sufficient to manage the general interests of the United States, could be drawn from any other source, or vested in any other authority, than that of the people at large; and I consider this authority the rock on which this structure will stand."

Neither Marshall nor Wilson feared the phrases, "Sovereign government," "Sovereign states." The states had such

${ }^{2} M c$ Culloch v. Maryland, 4 Wheaton, p. 402.

$=$ Elliott's Debates, vol 4, Appendix, p. 6ro.

${ }^{2}$ Elliott's Debates, vol. 2, p. 444 . 
power as the people gave them; the nation had such power as the people-not the states-gave it; the Constitution was supreme over both, but the peopie could change, amend, even do away with the Constitution, if in the exercise of their sovereignty it should seem to them the proper thing to do. May it not, therefore, be, that from this cause their minds were free to act upon such constitutional questions as this we have just examined without fear that they should infringe too far upon the prerogatives of the states? That they should be building up a too-important power above and beyond them. Was it not, perhaps, the constant irritation caused by the ever-recurring debate about the sovereign states; the jealousy and the ill-feeling that the dislike of parting with any power caused in the several states, that made Wilson speak so strongly in his lecture upon"Law and Obligation," ereignty? He had felt the evil of this false position of the law. He had felt that if this country was to proceed upon the only principle possible to her in the position she had taken, it must be understood, and very thoroughly understood, that sovereignty was the prerogative of the people, solely and unalterably. This it was that gave him such a firmness, such a clearness in his discussion of this and similar questions, it seems beyond doubt. This being so, it may not be inappropriate to reproduce here a part of his argument before the convention of Pennsylvania, words which helped to secure the adoption of that constitution to which he was so devoted.

After stating the aims of the constitutional convention of I787; the desire to frame for the consideration of their constituents, one federal and national constitution, "whose beneficence and energy would pervade the whole union, and bind and embrace the interests of every part," he says:

"We are now naturally led to examine the means by which they propose to accomplish this end. This opens more particularly to our view the important discussion before us. But previously to our enter-

'Wilson's Works, vol. I, p. 55. Phila. I804 
ing upon it it will not be improper to state some general and leading principles of government, which will receive particular applications in the course of our investigations."

"There necessarily exists in every government a power from which there is no appeal, and which, for that reason, may be termed supreme, absolute, and uncontrollable. Where does this power reside? To this question, writers on different governments will give different answers. Sir William Blackstone will tell you that in Britain, the power is lodged in the British parliament; that the parliament may alter the form of the government; and that its power is absolute and without control. The idea of a constitution, limiting and superintending the operations of legislative authority, seems not to have been accurately understood in Britain. There are, at least, no traces of practice conformable to such a principle. The British constitution is just what the British parliament pleases. When the parliament transferred legislative authority to Henry the Eighth, the act transferring it could not, in the strict acceptation of the term, be called unconstitutional."

"To control the power and conduct of the legislature by an overruling constitution; was an improvement in the science of government reserved to the American States."

"Perhaps some politician, who has not.considered with sufficient accuracy, our political systems, would answer, that in our governments, the supreme power was vested in the constitutions. This opinion approaches a step nearer the truth, but does not reach it. The truth is, that, in our governments, the supreme, absolute, and uncontrollable power remains in the people. As our constitutions are superior to our legislatures, so the people are superior to our constitutions. Indeed the superiority, in this last instance, is much greater; for the people possess; over our constitutions, control in act, as well as right."

"The consequence is, that the people may change the constitutions, whenever, and however they please. This is a right, of which no positive institution can ever deprive them." . . .

"Oft have I viewed with silent pleasure and admiration the force and prevalence, through the United States, of this principle that the supreme power resides in the people, and that they never part with it. It may be called the panacea in politics. There can be no disorder in the community but may receive a radical cure. If the errour be in the legislature, it may be corrected by the constitution; if in the constitution, it may be corrected by the people. There is a remedy, therefore, for every distemper in government, if the people are not wanting to themselves. For a people wanting to themselves, there is no remedy; from their power, as we have seen, there is no appeal; to their errour, there is no superiour principle of correction.".

"If we take an extended and accurate view of it, we shall find the streams of power running in different directions, in different dimensions, and at different heights, watering, adorning, and fertilizing the fields and meadows through which their courses are led; but if we trace them, we shall discover that they all originally flow from one abundant fountain. In this Constitution, all authority is derived from THE PEOPLE." "s

\section{Margaret $C$. Klingelsmith}

w Wilson's Works, vol. 3, pp. 291, 295. Phila. I804. 